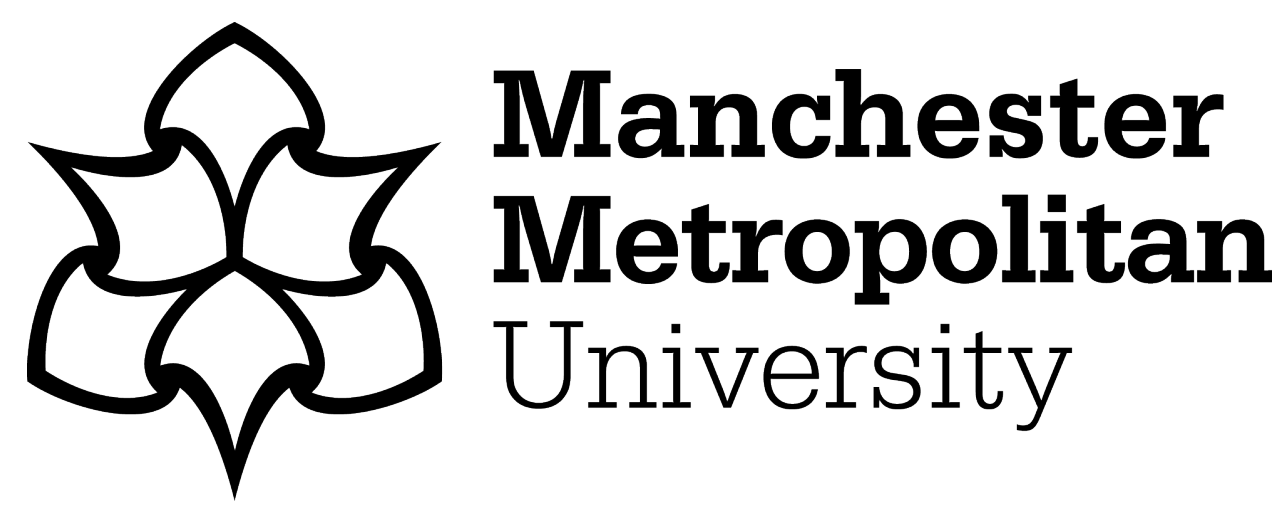

Naude, P ORCID logoORCID: https://orcid.org/0000-0002-4019-0393 and Sutton-Brady, C (2019) Relationships and Networks as Examined in Industrial Marketing Management. Industrial Marketing Management, 79. pp. 2735. ISSN 0019-8501

Downloaded from: https://e-space.mmu.ac.uk/622846/

Version: Accepted Version

Publisher: Elsevier

DOI: https://doi.org/10.1016/j.indmarman.2019.03.006

Usage rights: Creative Commons: Attribution-Noncommercial-No Derivative Works 4.0

Please cite the published version 


\title{
Relationships and Networks as examined in Industrial Marketing Management
}

\author{
By \\ Peter Naudé ${ }^{\mathrm{a}}$ \\ Manchester Metropolitan University Business School, Manchester, UK \\ The University of Sydney Business School, Sydney, Australia \\ p.naude@mmu.ac.uk \\ And \\ Catherine Sutton-Brady \\ The University of Sydney Business School, Sydney, Australia \\ Catherine.suttonbrady@sydney.edu.au
}

a Corresponding Author 


\title{
Relationships and Networks as examined in Industrial Marketing Management
}

\begin{abstract}
The importance of the study of relationships and networks within business-to-business marketing is clear from the numerous articles written over the years that aim to give us greater insight into these two concepts. This paper reviews six of these articles. What sets these six apart from others is that they are the most highly cited articles on relationships and networks published in Industrial Marketing Management between 1995 and 2004. We examine each of these articles in terms of their scholarly impact and identify what researchers have learnt from these highly cited papers. Our conclusions show some interesting similarities that we feel has led to these articles being so highly cited. We conclude that the key to citation success is the identification of new researching avenues. In addition, the chances of writing excellent papers seems to be improved when collaborating with others, rather than writing alone. By introducing new ideas these authors have not only been successful in their own work, but have given others the platforms to build on, thereby generating much more research in this area.
\end{abstract}

Keywords: Relationships, Networks, Citation statistics. 


\section{Relationships and Networks as examined in Industrial Marketing Management}

\section{Introduction}

In this article we examine six papers that have been published in Industrial Marketing Management and which focus on the broad themes of Relationships and Networks. The articles were selected on the basis of being the most highly cited papers covering either of these two topics. All six papers fall into the category of being in the top 30 most cited articles in the journal (see Table 4 in Möller and Halinen, 2018). The papers were published between 1995 and 2004, and their details are shown in Table 1 below.

Insert Table 1 about here

Each of these papers will be discussed in order of their publication. We then seek to draw out some conclusions that pertain to them as an overall collection of work, examining what lessons they may give us as researchers as we attempt to write work that reaches the high standard of the papers cited.

\section{Davies, Leung, Luk \& Wong (1995)}

The paper by Davies et al. (1995) explores the benefits of Guanxi by highlighting the value of personal relationships in Chinese business interactions. It is significant in that it is one of the first articles to attempt to understand the role of Guanxi, reinforcing the obvious argument that being first to publish in an area of research leads to a higher citation count. The paper 
with 708 Google citations and 335 Scopus citations continues to be well cited, with an average of 20 citations a year. The study provides a discussion of the benefits of Guanxi, and introduces the increasing importance of the Chinese market. It identifies the cultural context, most importantly the role of personal relationships in comparison to transactions governed by contracts.

This paper led the way for others that followed, and provided a basis for understanding the benefits of Guanxi. It acknowledges that 'the importance of Guanxi is well-established' ( $\mathrm{p}$. 210), but points out that previous studies had looked at it from the point of view of Western executives and that 'None of the previous research has attempted to identify the specific benefits that arise from the development of Guanxi, as seen by those on the inside or in areas of activity in which it is most important.' (p.210)

The study surveyed Hong Kong Chinese executives and the findings resulted from 150 useable questionnaires. Focus groups had helped the authors to identify three general headings under which specific benefits of Guanxi could be examined. These were 'sources of information', 'sources of resources' and 'other areas'. The first category of benefits, sources of information, included aspects such as information on market trends, government policies, import regulations and business opportunities. The authors argue that '..Guanxi networks can be an important source of information... When the "rule of man" is more important that the "rule of law", access to the person becomes an important substitute for access to the law." (p. 211)

The second category, sources of resources, was considered important because of the difficulty experienced by many managers in gaining access to resources as a result of central or local 
government control. The authors argue that 'managers suggested that Guanxi also yields benefits in respect of securing access to tangible resources in the form of land, labor, raw materials, and electricity, as well as resources in the form of rights, such as import licenses, local government approval, and central government approvals' (p.212).

The final catch-all 'others' category included smoothing transportation, facilitating the collection of payments, and building company reputation. The survey asked the respondents to rate the importance of each of these hypothesised benefits. The benefits receiving the highest ratings were those concerned with smooth running of routine and frequent transactions, information and access to resources, in that order. The most interesting part of the paper is therefore the managerial implications of these findings. Clearly the establishment and maintenance of 'good' Guanxi is vital for doing business in China as it allows the managers to take advantage of these benefits. The paper does give some insights into establishing Guanxi, arguing that "By bestowing favor and face through considerate and sensitive giving of minor gifts, hosting appropriate dinners, and (most importantly) giving personal attention, a businessperson can demonstrate the good faith that forms the basis for a gradual transition from outsider to insider.' (p. 213)

These insights do not, however, appear to come from the quantitative research itself and come across more as the opinions of the authors. It is therefore necessary in understanding the establishment and development of Guanxi to look to later papers for a more objective view of this issue (this has been done for example in papers by Chen and Chen 2004, and Warren, Dunfee \& Li 2004). 
Although it is one of the most highly cited papers in Industrial Marketing Management, we suggest that this is mainly due to the fact that it was one of the first to be published in the area. There are, however, a number of issues that would require one to look beyond this paper to better understand Guanxi. It was based on a sample of 150 Chinese mangers in Hong Kong at a time when Hong Kong was still a British Territory, given that is was only was returned to China in 1997. Whether this fact influenced the views of the Hong Kong mangers is unclear. At the time of publication China was a growing economy, and expected to become one of the world's largest economies. The paper's call for the need to take China seriously as a world market was prophetic, with China now considered by many economists to be the world's largest economy (Bloomberg 2017). Investigating Guanxi and its benefits in the China of today may give us a more nuanced picture.

While this paper was definitely not the first to discuss the notion or role of Guanxi (see, for example, Alston 1989, and Brunner, Chen, Chao \& Zhao 1989), it caught the attention of many academics, especially those working in the general area and trying to better understand B2B relationships in different cultural settings. What is interesting to scholars in the area of networks and relationships is that this paper makes no mention of trust, which over time has become synonymous with Guanxi (Leung, Chan, Lai \& Ngai 2011). The latest research in Guanxi has expanded greatly on this paper and a recent article to cite it clearly shows how far this research has evolved since 1995. Lee, Tang, Yip \& Sharma in their 2018 paper note that 'the conceptual definition of Guanxi has evolved from a unidimensional construct based on qualitative and descriptive studies (e.g. Davies et al., 1995) to a more complex multidimensional measurement construct' (p.357). 
Most studies now acknowledge Guanxi as consisting of the three dimensions of renqing, xinren and ganging. Renqing is considered to be the set of social norms needed to 'get along', xinren is often closely associated with trustworthiness, and ganging is concerned with feelings and attachment (Wang 2007). So the unidimensional approach taken by Davies et al., while introducing us to the benefits of Guanxi in general, has been surpassed theoretically by the research which continues to cite it, and this new literature gives managers even greater insights into the benefits of Guanxi. A second interesting aspect is the extent to which this paper launched a whole new research stream, in terms of trying to understand not just Guanxi, but also to understand the particularities of studying how relationships are managed in other cultural contexts (see, for example, Abosag \& Lee 2013, and Abosag \& Naudé, 2014).

\section{Möller \& Halinen (1999)}

This lead article for a Special Issue on Managing Business Networks and Relationship is significant in that it sets the stage for much of Möller's future work on Network Management (Möller \& Svahn 2003, Järvensivu \& Möller 2009, and Möller \& Halinen 2017). It attempts to identify the range of factors that make networks increasingly complex, and therefore difficult to operate in and manage. The major contribution of the article is the provision of a network management framework, in which it proposes a need to distinguish between four levels of issues in the complexity of managing networks;

'Industries as networks - network visioning

Firms in networks - net management

Relationship portfolios - portfolio management

Exchange relationships - relationship management' (p. 417). 
At the first level, 'industries as networks', the key challenge for managers is how to view the relevant networks, to understand the network evolution, and how to analyze strategic groups of firms. Developing a view of networks allows managers not only to see the opportunities within their networks, but also to understand network competition. As we argue later, subsequent work on network visioning, network pictures and strategic nets found much of its inspiration from this original work (Möller \& Svahn 2003, Abrahamsen et al. 2016).

Level two introduces the notion of 'focal nets' and contends that 'firms' strategic behavior in networks can be analyzed through the focal nets they belong to and through the positions and roles they play in these nets' (p.417). Since the publication of this article, many others have examined strategizing in business networks through the lens of position and role (see, for example, Gadde et al. 2003, Abrahamsen et al. 2012).

Level three highlights the importance of managing a portfolio of exchange relationships. The key at this level is developing an optimal portfolio. Finally, the capability to create and manage important relationships is central to level four. Providing this framework has led to this paper being highly cited as it gives the range of different mindsets that a B2B marketer must adopt in operating in an increasingly complex context - which is infinitely more than attempting to optimise a set of marketing mix variables. With 872 Google scholar citations and 276 in Scopus, it continues to make an impact with an average of 20 Scopus citations a year in recent years.

One of the reasons for the resonance of the article relates to timing: it is not that networks were something new in 1999, but rather that the article captured a point in time that saw a 
change in how industry generally was being restructured. As the paper argues, the whole trend towards focusing on core competencies and outsourcing other more peripheral activities meant that there were increasing levels of intensity in interfirm interactions. This in turn heightened the requirement for different management capabilities, given that the level of interdependency increased in which "traditional markets are being replaced by networks of interrelated firms and other actors, such as research and governmental agencies" (pg. 414).

The call for more research on network management is uppermost in this article. 'How to create and manage network positions, how to develop strategic nets, and how to gain entry into new networks are clearly highly topical managerial issues where more research is needed' (p.420). Möller responded to this challenge, and this article served as a starting point for his subsequent and often controversial network management work (Möller \& Svahn 2003, Järvensivu \& Möller 2009). Indeed Möller \& Halinen (2017) state that 'Even after two decades of research, network management is a strongly progressing, but also controversial domain" (p. 13). Their 2017 Special Issue in Industrial Marketing Management 'Managing Business and Innovation Networks' aimed to quell this controversy and to "provide an independent contribution to the advancement of network management research" (p.5).

It is evident that in the time since this article was published, various authors have given much thought to the issue of network management. In referring to this article Möller \& Halinen (2017) subsequently make the same point that "Since then, research has extended vastly in terms of perspectives applied.... as well as the sheer number of published studies. A dozen or so special issues on network management have been published in the IMM alone and the individual contributions across business marketing, strategy and management exceed a thousand." (p.5) 
In their 2017 article Möller \& Halinen provide an excellent overview of the evolution of business network management research taking us from strategic nets and strategizing in business networks in 2000 through the cognitive and knowledge perspectives to the institutional view which extends and challenges network management, and finally to innovation networks which aim to uncover network orchestration. The 2017 special issue, as the title indicates, looks at continued evolution to ecosystems. While it is obvious how far this research has come it is also clear that there is still scope for major contributions in this domain.

Möller \& Halinen (2017) use this lead article to propose a new framework, which 'consolidates the main streams and elements of the last decade of network management research into the contributions in this special issue' (p. 16). The Network Management Framework (Netframe) aims to provide a 'general theory of network management' (p.17). Based on Netframe they came up with a set of priorities for future research in the area. These include

'Examining management in the emergence of business fields of varying complexity, novelty and systematic characteristics.

Examining networked construction of different type of new focal ecosystems of varying complexity, novelty and systematic characteristics.

Business fields consist of several interwoven business networks in different phases of development. A neglected issue has been how to orchestrate or coordinate interlinked networks. 
Examining features and opportunities of dualistic or other dispersed forms of network agency.

All these research domains would benefit from research on network performance at both network and actor levels.

Finally we have a very limited knowledge of value-appropriation in various network or ecosystem modes.' P.21

The authors call for programmatic research to address these priorities and it is clear that despite so much research having been undertaken since their 1999 article, there is still scope for more investigation. This article has, by virtue of being one of the earliest written in this area, made a significant contribution to the research in network management and its high citation count is testament to this.

\section{Bengtsson \& Kock (2000)}

As in the previous two articles evaluated, the citation count on this paper benefits from its early publication. Although not the first paper to use the term coopetition, it arrived early enough to contribute significantly in this area, especially in a B2B marketing context, as the previous papers discussing the topic were published mainly in management journals (Dowling et al. 1996, Nalebuff and Brandenburger 1997). With 1929 Google citations and 723 Scopus citations, it is the most highly cited of the six papers that we reviewed. It had a significant spike in citations in 2016, which can be attributed to two special issues on coopetition, one in Industrial Marketing Management (Bengtsson et al. 2016) and the other in International Studies of Management \& Organization (Le Roy et al. 2016), which accounted for over one third of its citations in that year. 
The first user of the term coopetition is thought by many to be Ray Noorda, the founder of the networking software company Novell (Nalebuff \& Brandenburger 1997). As these authors note, "A company has to keep its eye on both balls, creating and capturing, at the same time. We have chosen to call this "co-opetition," because it combines competition and cooperation" (Nalebuff, \& Brandenburger 1997, pg. 28). Bengtsson \& Kock (1996) were clearly at the forefront of this research in marketing as their early work came out around the same time. At the outset they propose their definition of coopetition to be "The dyadic and paradoxical relationship that emerges when two firms cooperate in some activities, such as in a strategic alliance, and at the same time compete with each other in other activities is here called “coopetition." (pg. 412)

They note that coopetitive relationships are complex, and "it is argued that the most complex, but also the most advantageous relationship between competitors, is 'coopetition' where two competitors both compete and cooperate with each other. Complexity is due to the fundamentally different and contradictory logics of interaction that competition and cooperation are built on" (p. 411).

Bengtsson \& Kock's work was based on an exploratory case study of one Finnish and two Swedish industries. They undertook 21 interviews across the three industries. The rich data was then used "to develop propositions about how the competitive and cooperative part of the relationship can be divided and managed." (p.411).

They argue that there are "at least three different types of coopetitive relationships depending on the degree of cooperation and competition" (p. 415). These are cooperation-dominated, competition-dominated and those in which cooperation and competition are equally 
distributed. They argue that the two aspects can be separated by looking at two activities the degree of proximity to the customer and on the competitors' access to specific resources. Their discussion on closeness to customer emerged from their fieldwork and intuitively makes sense. They maintain that "In these relationships, competitors cooperate with activities far from the customer and compete in activities close to the customer" (pg. 418). Their rationale is an obvious one in that you do not want to cooperate in activities close to the customer if it means you may lose those customers to the other party as a result of the cooperation. However they contradicted this notion in the example they gave on pg. 420 in which the two companies Milka and Valio cooperate close to the customer, which clearly goes against what they maintain is one of their main findings. They do explain that this arises from Milka's need for a full product line and that Valio, although the market leader elsewhere in Finland, benefits from accessing the Swedish and other bilingual areas where Milka is market leader. We feel that this could be addressed by testing their second proposition, and it may be found in some relationships that closeness to customer is not the factor that separates competition from cooperation ("Proposition 2: The cooperative and competitive parts of a coopetitive relationship are divided due to the closeness of an activity to the customer, in that firms compete in activities close to the customer (output activities) and cooperate in activities far from the customers (input activities)" (p.421)).

In total Bengtsson \& Kock provide 6 propositions, concerning heterogeneity in resources, the closeness of an activity to the customer, the extent to which networks affect the decision to cooperate or not, conflict management, the separation of interactions (as it is more difficult for individuals to cooperate and compete simultaneously, although the organization can), and the advantage of coopetition. While these propositions are interesting, they have limited value in that they are not further tested in the article, and as a result the paper essentially provides 
us with a simple typology of relationships. This typology does however provide a fruitful agenda for future research and debate in this area.

We feel that one of the reasons that the paper is so highly cited, is that it was the first to show that at a dyadic level "coopetition entails simultaneous collaboration between two companies" (Pattinson et al. 2018, pg. 25) and secondly, that it provides a typology of these relationships. This approach to managing dyadic relationships has obviously attracted the attention of B2B marketers, and has led to a significant amount of subsequent work in the area, and we would agree that interest in coopetition research has been on the increase (Bengtsson \& Raza-Ullah 2016).

The most recent papers in the area of coopetition research have advanced to look at a multilevel understanding of the concept. Bengtsson \& Raza-Ullah (2016) developed a multilevel model of coopetition "that incorporates multilevel linkages of coopetition, and suggests how coopetition in the network context effects dyadic coopetitive relationships and vice versa” (pg. 35).

We suggest that the high level of citations for this paper is a result of the authors being the first to use the phrase in a B2B context and provide a definition, which resonates with $\mathrm{B} 2 \mathrm{~B}$ researchers. Secondly, the special issues in 2016 rejuvenated interest in the area and accounted for the resurgence in citations. Coopetition research has advanced well since this paper was first published, but the typology it provides has given others a platform to build on and understand the multilevel nature of the concept. 


\section{Walter, Müller, Helfert \& Ritter (2003)}

The study of the quality of long-term buyer-seller relationships has formed a core part of B2B research over the years (e.g. Dwyer et al. 1987, Dorsch et al. 1998, Naudé and Buttle 2000). As competitive pressure increases and supply chains become increasingly tightly managed, it is clear that companies are going to select those suppliers who deliver better quality products and services in the relevant market. What is less well understood, however, is what the possible antecedents of relationship quality are, and that is what this paper explores: from the buyers' perspective, just what are those actions that the sellers can undertake in an attempt to improve relationship quality?

The authors take the viewpoint that relationship quality is a higher-order construct, made up of three distinct but inter-related dimensions of trust, commitment, and satisfaction (based on the earlier work of Dorsch et al. 1998). The authors create a very sound generation of measures for each of these constructs based on affective, instrumental and temporal dimensions of commitment; benevolence, honesty, and competence to measure trust; and four different measures of satisfaction.

The antecedents of the level of relationship quality experienced by the buyer is argued by the authors to be based on two different sets of actions by the seller: direct functions and indirect functions. This is based on the earlier work of Anderson et al. (1994) and also of Håkansson \& Johanson (1993), who divide the impact of the functions into direct (aka first order or primary) and indirect (second/third order or secondary) effects.

The direct functions are defined as those that benefit the relationship directly, and "do not depend on other relationships or actors" (pg. 161). Four such direct functions carried out by 
the seller are identified: cost reduction, providing a quality product, the volume provided, and a safeguarding or back-up function to be used when a different supplier is suddenly required. Indirect relationship functions on the other hand "are beneficial for the customer only in other relationships or in the future' (pg. 161). Four of these are identified: a market function, when the supplier helps the customer to identify new possible markets; a scout function in which information is passed on to the customer; an innovation development function whereby the supplier helps the customer develop more innovative offerings; and a social support function which seeks to keep the relationship functioning smoothly. The scales used were a combination of previously published work some developed specifically for this study. It is hypothesised that both direct and indirect functions will have a positive influence on relationship quality. However, Walter et al. argue that different market and situational contexts might moderate this relationship. Based on the earlier work of Anderson \& Narus (1990) and also of Cannon \& Perrault (1999), they argue that the availability of alternative sources of supply $\left(\mathrm{Cl}_{\mathrm{alt}}\right)$, or replaceability, would moderate the strength of the association. A survey was undertaken based on a sample of 230 purchasing professionals across a range of industries in Germany, who were answering on behalf of an important supplier "who was sufficiently important to warrant relational exchange behaviors" (pg. 163). Following appropriate tests to confirm the measurement model, the data was analysed using structural equation modelling. As expected, the hypotheses regarding the impact of both direct and indirect functions were found to have a direct and positive impact on relationship quality. Moreover, the moderation tests showed that the impact is stronger when the customer is in a position to readily replace the supplier.

This paper was originally presented at the IMP Conference in Manchester in 2000 (Leek et al. 2003). What makes it such a well-referenced paper? The paper is soundly written and well 
executed, with excellent data analysis. It is among the very early works to study the antecedents of relationship quality, concluding that "perceived quality depends on functional inputs" (pp. 165). And, as the authors note, the paper makes an innovative contribution in terms of construct measurement, treating relationship quality as a second order construct. We suggest that the reasons for its success go beyond this. There have been lengthy discussions at recent IMP Conferences as to the lack of theoretical developments in the field beyond the original discussions surrounding interaction, relationships, and networks. Our opinion is that this rather misses the point. There is indeed a great deal of developmental work that has been happening within B2B marketing recently, but it has concerned developments in methodology rather than theory. This paper serves as an excellent example of early work in the IMP tradition that started to adopt more rigorous analytical approaches.

\section{Zablah, Bellengfer, \& Johnston (2004)}

This paper was one of the first in Industrial Marketing Management to deal explicitly with Customer Relationship Management systems - a slightly earlier one was the work undertaken by Campbell (2003). In this 2004 paper Zablah et al. build on earlier work undertaken at Georgia State University by Wesley Johnston and his colleagues on the same topic (Borders et al. 2001). This 2004 paper was one of seven that formed an Industrial Marketing Management Special Issue specifically on the topic of customer relationship management. The 771 citations for Zablah et al.'s paper amount to $45 \%$ of all the citations for the articles making up the Special Issue, a testament to the quality of the paper.

The introduction to the paper describes the scene at the time it was written, noting the high failure rate of many commercial CRM implementations. The authors attribute this to the highly fragmented understanding of exactly what CRM is, noting that academics and 
practitioners alike could not agree on just what it encompassed. To some it was seen as " $a$ specialized collection of technological tools, other stress it is a set of business processes that focus on managing the customer experience, and still, others propose that it is best conceptualized as a comprehensive strategy for customer retention" (pg. 476).

One of the innovative features of this paper is that it was an early attempt to identify the different perspectives that existed on what this emerging phenomenon really was. Based on an analysis of the published literature at the time and also on a range of CRM web portals, the authors identified five different dominant conceptualizations of CRM. These were:

CRM as process: seeing it as a number of different activities, for example customer knowledge creation and the data collection that is required to enact it, that are then all combined to offer valuable insights. From this perspective, CRM cannot be seen as a singularity, since the outcome of the process "depends entirely upon how the constituent activities are aggregated" (pg. 476). They note that there are two variants of seeing CRM as a process: at the macro-level it consists of "activities that firms undertake ... to build durable, profitable, mutually beneficial customer relationships," (pg. 477) while at the micro-level it is more concerned with optimally managing specific interactions.

CRM as strategy: This perspective starts by recognizing that all customers are not (or at least should not) be seen as being equally important. Instead, the lifetime value of customers to the supplier will vary, an approach that suggests that firms should take a portfolio approach to managing their customer base.

CRM as a philosophy: From this viewpoint, CRM is seen not as an IT project, but as an overall guiding principle concerning how to achieve customer centricity. As the authors note, this approach links the marketing concept and relationship management, and "focuses on the importance of creating customer value, something that is only implied in the other 
perspectives" (pg. 478).

CRM as a capability: Taking a capability perspective revolves around seeing relationship management not as a single task, but rather as a variable one, with firms having the knowledge, resources and capability to constantly adapt the way in which relationships are managed. As the authors note, "Although the capability view of CRM has not received widespread support in the literature, it does serve to emphasize that a certain mix or resources are needed to effectively manage customer relationships" (pg. 478).

CRM as technology: The argument is made that some see CRM as a technology, but that this is too simplistic a view - there is a certain level of technology underpinning any CRM system implementation, but that this "only has a moderate to weak impact on the overall success of firms' relationship building efforts"' (pg. 479).

One of the reasons for this paper's success has been the identification of these different viewpoints, and weaving them together to paint a more comprehensive picture of what CRM really is, and that "the macroprocess view provides the best conceptual foundation for the CRM phenomenon" (pg. 479). The authors go on to discuss the overlap between relationship marketing and CRM and argue, correctly in our view, that they "are different phenomena that warrant a distinction in the literature" (pg. 481), given that any good CRM system has to be capable of helping to manage buyer-seller relationships across the transactional - relational continuum. This reminds us that the much-used 'relationship marketing' phrase is often too simplistic. Certainly in many B2B environments we find very close relationships, but there are still interactions that are more hands-off and transactional. In order to operationalise such a system at this macro-level, the paper argues that CRM consists of integrating the two different processes of the knowledge management and the interaction management, both of which are explored in greater depth. 
This paper was one of the first to examine systematically the emerging phenomenon of CRM. The importance of the topic was just being recognised, with a special section of the Journal of Marketing (Boulding et al. 2005) being focused on the same topic shortly thereafter, in which one paper in particular (Payne \& Frow 2005) builds on this paper in describing their 'CRM Continuum.'

\section{Ritter, Wilkinson \& Johnston (2004)}

This paper was presented originally at the IMP Asia conference that was held in Perth in 2002. The best papers from that conference were organised into a Special Issue of this journal (for an excellent discussion of the value co-creation resulting from the IMP Conference-IMM Special Issue interaction, see Möller \& Halinen 2018). This Ritter et al. paper was one of nine selected, and with 808 citations, it has more than the other top three articles combined.

There are numerous articles within Industrial Marketing Management that explore the nature of relationships and networks in business-to-business marketing. What sets this paper apart is that it is explicitly managerial, seeking to examine how managers manage in their complex environment. As such, this paper follows on and develops the logic of the earlier Möller \& Halinen (1999) paper, while taking a more managerial rather than theoretical line. The focus moves on from attempting to understand the nature of relationships and networks to trying to understand how to manage in these situations. The paradox here is that the authors note that managers can often not manage as fully as some text books would have us believe. They note that "Firms are seldom in total control of all these relationships and are subject to the control and influence of others within and around the relationship ... business networks are not generally under the control of an individual firm but are self-organizing systems, in 
which order emerges in a bottom-up fashion from the local interactions taking place among firms in the relationship" (pg. 175).

In shifting the focus from understanding to managing, the paper seeks to answer two questions: to what extent a can managers manage their network, and how can managers' ability to manage a network can be characterized and measured. In answering the first question, the authors build on the earlier work of Branderburger \& Nalebuff (1996) and conceptualise a firm's value net as consisting of all the relationships between actors within the focal company as well as with customers, suppliers, competitors and other complementors. In managing in these complex systems, the authors contrast the traditional viewpoint whereby firms are seen as being in control of their own actions with the observation that we often find that firms "are not in total control over their resources as other actors influence or restrict actions taken by a given firm.... In this view, firms and networks of firms are seen as complex adaptive systems that are not centrally directed ... From this point of view networks are unmanageable, in the sense of being controlled and directed by a single participant firm" (pg. 177). The authors then develop a typology of relationships based on the power that two interacting firms have over each other, arguing that this determines the relationship type and the degree to which firms can or cannot act independently. This is a theme that has been examined subsequently in some depth by IMP scholars, for example in looking at the conform or confront, consolidate or create, and coerce or concede options between which managers have to choose (Ford et al. 2011).

In answering the second question, the paper notes that there are different levels of relationship and network management, varying from a single actor at one extreme through to dyads, portfolios, connected relationships and ultimately the whole network, with the 
managers concerned facing different tasks according to the level on which they are focusing. In particular, this depends on whether the task is relationship-specific, in which the managerial task is one of managing interaction in just one relationship, or the more typical and difficult - cross-relational task of simultaneously managing numerous interconnected relationships. In attempting to answer their two questions, Ritter et al. develop six propositions through which they believe "shed some light on the nature of networking ability" (pg. 181). As they note, however, "the current understanding of network management is limited, which poses implications for managers and researchers alike" (pg. $181)$.

\section{Concluding comments}

Having reviewed each of these six papers, what can we conclude? First, Table 1 above painted a very rosy picture of how well referenced these six papers have been. In Table 2 we identify what we feel to be the main contributions of each of the papers. Table 3 below gives perhaps a more nuanced picture, in which we examine the extent to which they have been referenced in a selection of 12 of the more mainstream journals in the area. We show here the Scopus Citations per year and also the total citations that have appeared in these journals. Two different issues are raised by this table: first, the articles are (by far) mostly cited in Industrial Marketing Management itself, with the Journal of Business and Industrial Marketing trailing by some distance. Secondly, the relative order has changed significantly: whereas the Bengtsson \& Kock article received the most Google Scholar citations, if we look just at these twelve journals, then it is the work of Thomas Ritter and his colleagues that is most highly cited. 
Insert Tables $2 \& 3$ and Figure 1 about here

And how do these citations vary over time? Normally, it is expected that citations "display scurve type behaviour: beginning slowly, rising in response to previous citations, and then declining as the material becomes obsolete" (Mingers 2008, pg. 1013). As shown in Figure 1, this appears not to be the case here for most of the papers - these seems to be more of a trend of 'bubbling along' at 20-30 citations each a year over the last 10 years. The one notable exception to this is obviously the Bengtsson \& Kock article, which benefitted from the two special issues on coopetition mentioned earlier.

Given that all of these papers focus on the broad area of relationships and networks, how do they relate to each other? In Figure 2 below we take the Network Management Framework introduced in the Möller \& Halinen paper, and use it to position the different papers. In their paper the authors identified the four different "levels of issues in the complexity of managing business networks” (Möller \& Halinen 1999, pg. 416) that were identified earlier. We relabel these slightly as being Managing Relationships, Managing Portfolios (of Relationships), Managing in Networks, and finally Network Visioning. This serves as a useful template to examine these six papers. We would argue that the three papers of Walter et al., Bengtsson \& Kock, and Davies et al. are all concerned with how to manage individual relationships in some optimal way, whereas Zablah et al. cast their net wider, and examine how CRM can be used by managers to optimally manage their overall portfolio of relationships. The Ritter et al. paper goes one step further and is concerned with how "a firm's ability to manage a network (can) be characterised and measured" (Ritter et al. 2004, pg. 175). The Möller \& 
Halinen paper takes a wider perspective and looks at all three levels. However, as they note, there is a paucity of work looking at network visioning, which they define as "management's skills and competencies in creating valid views of networks and their potential evolution" (1999, pg. 417). We would suggest that this approach will be of increasing interest to the B2B research community. Rather than a retrospective reflection of how networks have evolved or can be managed, it is concerned with understanding managers' forward-looking perspective, in which actors work together to consider how they can move things along a different network path (see, for example, Patvardhan 2013, Abrahamsen et al. 2016).

\section{Reflections}

Given our reading of these best-in-class papers, what conclusions do we reach as to what path to follow to try and emulate their success?

First, we have all experienced the steady rise in the quality of papers published in IMM, as Peter LaPlaca steadily and relentlessly tried to improve the quality of the submissions over the past few decades (Di Benedetto \& Lindgreen 2018). There is no doubt that it is getting ever more difficult to publish in top quality journals. However, given the direction of travel in the evolution of scientific methodologies, it has also never been easier - it is going to get even more difficult as new analytical approaches are developed and which will be expected by reviewers. So the way forward is clear - start writing now, because it will be (even) more difficult later on! ${ }^{1}$

The second point to note is that in spite of the increasing sophistication of the quality of statistical analysis that is expected, only one of these papers (Walter et al.) is a quantitative

\footnotetext{
${ }^{1}$ We are indebted to Prof. Andreas Eggert for this delightful observation!
} 
one (the Davies et al. paper does have come simple factor analysis in it). So the evidence is there, that in order to write a highly cited paper does not necessarily mean that it has to be quantitative. More important than this, we would argue, is that the subject matter has to be new. Davies et al. introduced the B2B research community to Guanxi, in the same way that Bengtsson \& Kock introduced coopetition from the broader strategy literature, and Zablah et al. were one of the first to try and provide a common managerial conceptualization of CRM systems. Therefore our second suggestion would be to constantly seek to understand and document emerging phenomena. For example, what potential can and does social media have in how B2B relationships are managed? What are the implications of digital marketing for B2B relationship management? Given the ever-increasing amount of data being stored, what can approaches such as netnography (Kozinets, 2002) tell us about how relationships are being managed in practice?

Thirdly, we note that the average number of authors across these 6 papers is 3 . Indeed, the average number of authors per paper covering all papers in Industrial Marketing Management during the 2015 - 2017 period is just under 3 . The message to young researchers therefore must be to not write alone - not only does "chance favour the connected mind" (Pagani 2018,pg. 131), but the evidence is also there that the chance of getting published favours the connected researcher. Working collaboratively increases the chances of getting published, so expand your network! This is still a relatively underexplored area, with Möller \& Halinen noting that the "literature is relatively silent about how (...) research contributions are created and disseminated, how various human and institutional actors collaborate to construct academic value. This is a major shortcoming, since a better understanding of academic value creation could improve the effectiveness of our research efforts in the field" (2018, pg. 18). 
In conclusion, these highly cited papers, in addition to making valuable contributions to theory, have spawned considerable research over time. Their early ideas have given others a platform on which to build, and have allowed the field of relationships and networks to be further enhanced. They have reached an academic standard that we should all aspire to. 
Figure 1

Citations over time

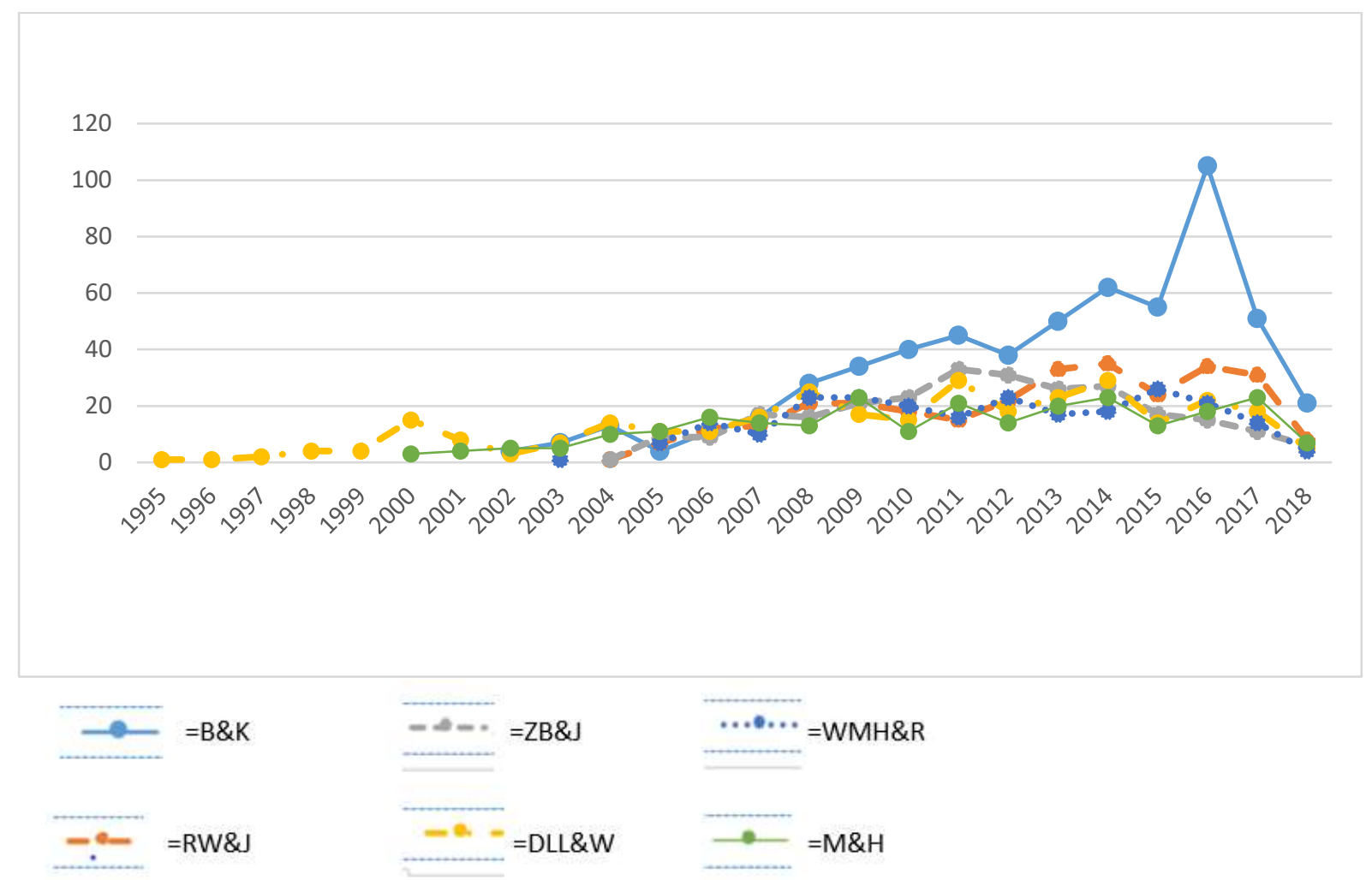


Figure 2

How the papers relate to each other

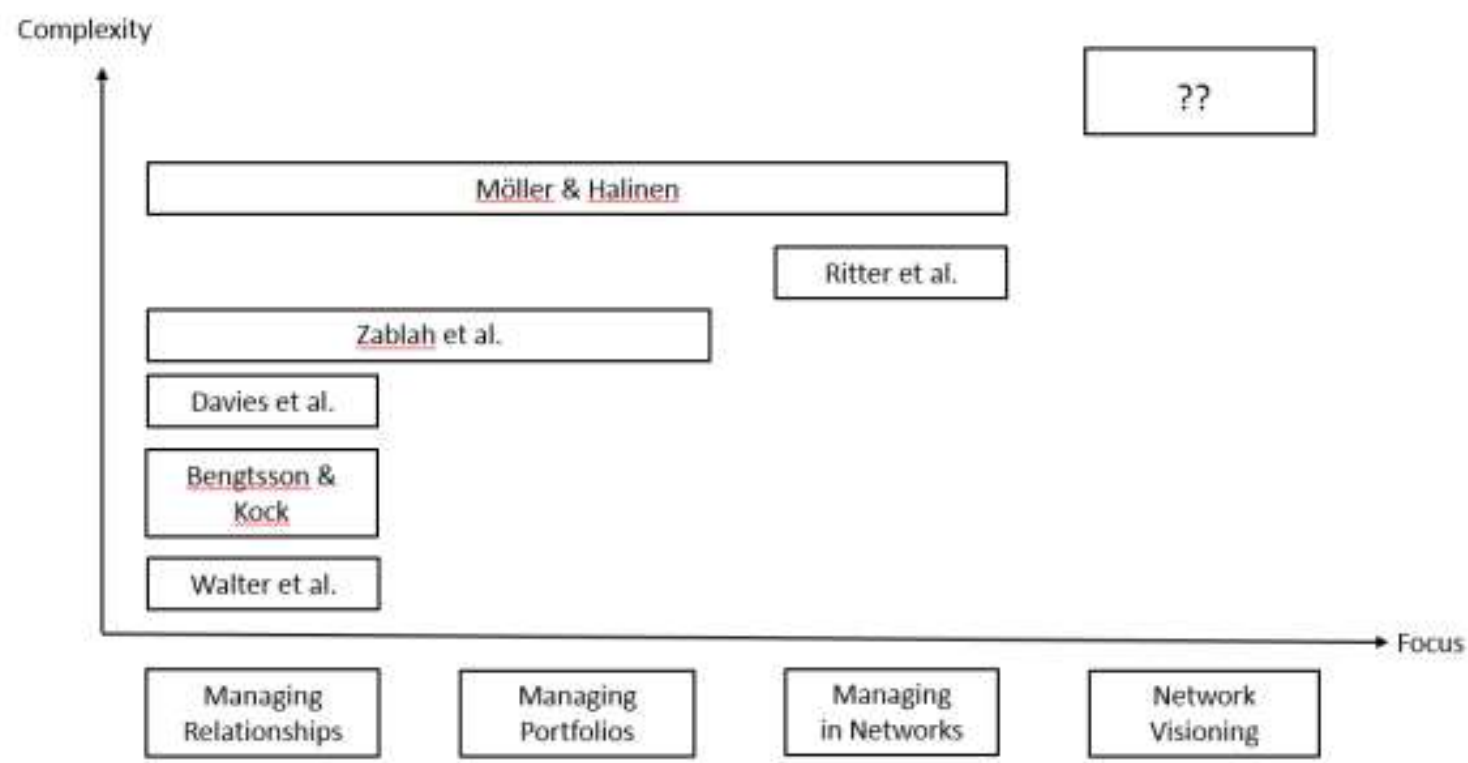

Source: Based on Möller \& Halinen, 1999 
Table 1

The six most highly cited papers on Relationships and Networks

\begin{tabular}{|c|c|c|c|c|}
\hline Authors & Title & $\begin{array}{c}\text { Date of } \\
\text { Publication }\end{array}$ & $\begin{array}{l}\text { Google } \\
\text { Scholar } \\
\text { Citations } \\
11 / 3 / 19\end{array}$ & $\begin{array}{c}\text { Scopus } \\
\text { Citations } \\
11 / 3 / 19 \\
\end{array}$ \\
\hline $\begin{array}{l}\text { Davies, } \\
\text { Leung, Luk \& } \\
\text { Wong }\end{array}$ & $\begin{array}{l}\text { The Benefits of "Guanxi" - } \\
\text { The Value of Relationships } \\
\text { in Developing the Chinese } \\
\text { Market }\end{array}$ & 1995 & 708 & 335 \\
\hline $\begin{array}{l}\text { Möller \& } \\
\text { Halinen }\end{array}$ & $\begin{array}{l}\text { Business Relationships and } \\
\text { Networks: Managerial } \\
\text { Challenge of Network Era }\end{array}$ & 1999 & 872 & 276 \\
\hline $\begin{array}{l}\text { Bengtsson \& } \\
\text { Kock }\end{array}$ & $\begin{array}{l}\text { "Coopetition" in Business } \\
\text { Networks - to Cooperate and } \\
\text { Compete Simultaneously }\end{array}$ & 2000 & 1929 & 723 \\
\hline $\begin{array}{l}\text { Walter, } \\
\text { Müller, } \\
\text { Helfert \& } \\
\text { Ritter }\end{array}$ & $\begin{array}{l}\text { Functions of industrial } \\
\text { supplier relationships and } \\
\text { their impact on relationship } \\
\text { quality }\end{array}$ & 2003 & 627 & 265 \\
\hline $\begin{array}{l}\text { Zablah, } \\
\text { Bellenger, \& } \\
\text { Johnston }\end{array}$ & $\begin{array}{l}\text { An evaluation of divergent } \\
\text { perspectives on customer } \\
\text { relationship management: } \\
\text { Towards a common } \\
\text { understanding of an } \\
\text { emerging phenomenon }\end{array}$ & 2004 & 771 & 290 \\
\hline $\begin{array}{l}\text { Ritter, } \\
\text { Wilkinson \& } \\
\text { Johnston }\end{array}$ & $\begin{array}{l}\text { Managing in complex } \\
\text { business networks }\end{array}$ & 2004 & 855 & 334 \\
\hline
\end{tabular}


Table 2

\section{Main contributions of the six papers}

\begin{tabular}{|l|l|}
\hline \multicolumn{1}{|c|}{ Authors } & \multicolumn{1}{c|}{ Contribution } \\
\hline $\begin{array}{l}\text { Davies, } \\
\text { Weung, Luk \& }\end{array}$ & $\begin{array}{l}\text { Establishment of good Guanxi allow benefits to accrue. These benefits were seen to } \\
\text { have an underlying structure of four factors characterised as "procurement, } \\
\text { information, bureaucracy, and transaction-smoothing" }\end{array}$ \\
\hline $\begin{array}{l}\text { Möller \& } \\
\text { Halinen }\end{array}$ & $\begin{array}{l}\text { This article provides a network management framework, in which it proposes a need } \\
\text { to distinguish between four levels of issues in the complexity of managing networks, } \\
\text { 'Industries as networks - network visioning, Firms in networks - net management. } \\
\text { Relationship portfolios - portfolio management, and Exchange relationships - } \\
\text { relationship management' (p. 417). }\end{array}$ \\
\hline $\begin{array}{l}\text { Bengtsson \& } \\
\text { Kock }\end{array}$ & $\begin{array}{l}\text { This study found that in relationships with simultaneous cooperation and competition } \\
\text { the closeness of activities to the buyers matters. That is that firms more frequently } \\
\text { cooperate in activities undertaken at a greater distance from buyers and compete in } \\
\text { activities closer to buyers. }\end{array}$ \\
\hline $\begin{array}{l}\text { Walter, } \\
\text { Müller, } \\
\text { Helfert \& } \\
\text { Ritter }\end{array}$ & $\begin{array}{l}\text { This article provides empirical evidence that the supplier's fulfilment of direct and } \\
\text { indirect functions for the customer has an impact on the customer's perception of } \\
\text { quality of the relationship. Functional inputs increase perceived relationship quality. }\end{array}$ \\
\hline $\begin{array}{l}\text { Zablah, } \\
\text { Bellenger, \& } \\
\text { Johnston }\end{array}$ & $\begin{array}{l}\text { To effectively practice CRM firms must have a clear understanding of what it } \\
\text { entails. This article proposes a conceptualization of CRM and provides a basic } \\
\text { framework for achieving CRM success. }\end{array}$ \\
\hline $\begin{array}{l}\text { Ritter, } \\
\text { Wilkinson \& } \\
\text { Johnston }\end{array}$ & $\begin{array}{l}\text { This article provides 6 propositions to help understand the nature of networking } \\
\text { ability, which they highlight as a key factor in allowing managers to maintain } \\
\text { effective and productive relationships. In essence networking ability is required to } \\
\text { manage your network. }\end{array}$ \\
\hline
\end{tabular}


Table 3

Citation Comparison in the Mainstream Journals

\begin{tabular}{|c|c|c|c|c|c|c|c|}
\hline Journal & $\begin{array}{l}\text { Davies et } \\
\text { al. (1995) }\end{array}$ & $\begin{array}{c}\text { Möller \& } \\
\text { Halinen } \\
\text { (1999) }\end{array}$ & $\begin{array}{c}\text { Bengtsson } \\
\text { \& Kock } \\
(2000)\end{array}$ & $\begin{array}{l}\text { Walter et } \\
\text { al. (2003) }\end{array}$ & $\begin{array}{l}\text { Ritter et } \\
\text { al. (2004) }\end{array}$ & $\begin{array}{l}\text { Zablah et } \\
\text { al. (2004) }\end{array}$ & $\begin{array}{l}\text { Total in } \\
\text { Journal }\end{array}$ \\
\hline $\begin{array}{l}\text { Australasian } \\
\text { Marketing } \\
\text { Journal }\end{array}$ & 0 & 0 & 0 & 5 & 3 & 0 & 8 \\
\hline $\begin{array}{l}\text { European } \\
\text { Journal of } \\
\text { Marketing }\end{array}$ & 2 & 2 & 0 & 5 & 3 & 2 & 14 \\
\hline $\begin{array}{l}\text { Industrial } \\
\text { Marketing } \\
\text { Management }\end{array}$ & 28 & 62 & 58 & 29 & 63 & 14 & 254 \\
\hline $\begin{array}{l}\text { Journal of } \\
\text { Academy of } \\
\text { Mktg. Sc. }\end{array}$ & 0 & 0 & 0 & 2 & 3 & 1 & 6 \\
\hline $\begin{array}{l}\text { Journal of } \\
\text { Bus. \& Ind. } \\
\text { Marketing }\end{array}$ & 5 & 14 & 11 & 22 & 30 & 10 & 92 \\
\hline $\begin{array}{l}\text { Journal of } \\
\text { Business } \\
\text { Research }\end{array}$ & 5 & 6 & 4 & 4 & 2 & 1 & 22 \\
\hline $\begin{array}{l}\text { Journal of } \\
\text { B-to-B } \\
\text { Marketing }\end{array}$ & 4 & 7 & 2 & 4 & 4 & 0 & 21 \\
\hline $\begin{array}{l}\text { Journal of } \\
\text { Marketing }\end{array}$ & 0 & 0 & 0 & 1 & 0 & 3 & 4 \\
\hline $\begin{array}{l}\text { Journal of } \\
\text { Marketing } \\
\text { Management }\end{array}$ & 2 & 5 & 1 & 3 & 5 & 0 & 16 \\
\hline $\begin{array}{l}\text { Journal of } \\
\text { Marketing } \\
\text { Research }\end{array}$ & 0 & 0 & 0 & 0 & 0 & 0 & 0 \\
\hline $\begin{array}{l}\text { Journal of } \\
\text { Purchasing } \\
\text { and Supply } \\
\text { Management }\end{array}$ & 2 & 0 & 4 & 9 & 1 & 0 & 16 \\
\hline $\begin{array}{l}\text { Supply } \\
\text { Chain } \\
\text { Management }\end{array}$ & 2 & 1 & 5 & 4 & 3 & 1 & 16 \\
\hline $\begin{array}{l}\text { Ave. Scopus } \\
\text { Cites/year }\end{array}$ & 10.8 & 17.8 & 34.1 & 15.4 & 19.8 & 18.1 & \\
\hline $\begin{array}{l}\text { Total cites in } \\
\text { these } \\
\text { Journals } \\
\text { (\% of all } \\
\text { Scopus } \\
\text { citations) }\end{array}$ & $\begin{array}{c}51 \\
(21.4 \%)\end{array}$ & $\begin{array}{c}99 \\
(32.5 \%)\end{array}$ & $\begin{array}{c}85 \\
(15.5 \%)\end{array}$ & $\begin{array}{c}88 \\
(38.1 \%)\end{array}$ & $\begin{array}{c}117 \\
(42.2 \%)\end{array}$ & $\begin{array}{c}32 \\
(12.6 \%)\end{array}$ & \\
\hline
\end{tabular}

Source: Scopus, 13/11/2017 


\section{References}

Abosag, I., \& J.-W. Lee (2013)

The formation of trust and commitment in business relationships in the Middle East:

Understanding Et-Moone relationships, International Business Review, 22/3 pp. 602614

Abosag, I. \& P. Naudé (2014)

The Development of Special Forms of B2B Relationships in Eastern Cultures:

Examining the Role of Interpersonal Liking in Developing Guanxi and Et-Moone

Relationships, Industrial Marketing Management, 43/6 pp. 887-896,

Abrahamsen, M., S.C. Henneberg, L. Huemer \& P. Naude (2016)

Network picturing: An action research study of strategizing in business networks.

Industrial Marketing Management. 59 pp. 107-119.

Abrahamsen, M., S.C. Henneberg, L. Huemer \& P. Naude (2012)

Using actors' perceptions of network roles and position to understand network

dynamics. Industrial Marketing Management, 41(2) pp. 259-269.

Alston, J.P. (1989)

Wa, Guanxi and Inhwa: Managerial Principles in Japan, China, and Korea, Business Horizons, 69, pp. 5-12.

Anderson E.W., C. Fornell \& D. R. Lehmann (1994)

Customer satisfaction, market share, and profitability: findings from Sweden, Journal of Marketing, 58, pp. 53-66

Anderson, J.C. \& J.A. Narus (1990)

A model of distributor firm and manufacturer form working partnerships, Journal of Marketing, 54, pp. 42-58

Bengtsson, M. \& S. Kock (1996)

Co-operation and Competition among Horizontal Actors in Business Networks, Paper presented at the $6^{\text {th }}$ Workshop on Interorganizational Research, Oslo, August 23-25, 1996.

Bengtsson, M., \& Kock, S. (2000)

Coopetition in business networks - to cooperate and compete simultaneously, Industrial Marketing Management, 29/5, pp. 411-426.

Bengtsson, M., S. Kock, E.L. Lundgren-Henriksson \& M.H. Näsholm (2016)

Coopetition research in theory and practice: Growing new theoretical, empirical, and methodological domains, Industrial Marketing Management, 57, pp. 4-11.

Bengtsson, M. \& T. Raza-Ullah (2016)

A systematic review of research on coopetition: Toward a multilevel understanding Industrial Marketing Management 57, pp. 23-39

Bloomberg (2017) 
https://www.bloomberg.com/view/articles/2017-10-18/who-has-the -world-s-no-1economy-not-the-u-s, accessed 15/5/2018

Borders, A.L., W.J. Johnston \& E.E. Rigdon (2001)

Beyond the Dyad: Electronic Commerce and Network Perspectives in Industrial Marketing Management, Industrial Marketing Management, 30 pp. 199-205

Boulding, W., R. Staelin, M. Ehret \& W.J. Johnston (2005)

A Customer Relationship Roadmap: What is Known, Potential Pitfalls, and Where to Go, Journal of Marketing, 69, pp. 155-166

Brandenburger, A.M. \& B.J. Nalebuff (1996)

Co-opetition, Double Day, New York.

Brunner, J., J. Chen, S. Chao \& N. Zhao (1989)

The role of "Guanxi" in Negotiations in the Pacific Basin, Journal of Global Marketing, 3, pp. 7-23.

Campbell, A. J., (2003)

Creating customer knowledge competence: managing customer relationship management programs strategically, Industrial Marketing Management, 32/5, pp. 375383

Cannon, J.P. \& W. D. Perrault (1999)

Buyer-seller relationships in business markets, Journal of Marketing Research, 36, pp. 439-460

Chen, X-P. and Chen, C. C. (2004): On the Intricacies of the Chinese Guanxi: A Process Model of Guanxi Development, Asia Pacific Journal of Management, 21/3, pp. 305324.

Davies, H., T.K.P. Leung, S.T.K. Luk \& Y. Wong (1995)

The Benefits of "Guanxi" The value of Relationships in Developing the Chinese Market, Industrial Marketing Management, 24, pp. 207-214

Di Benedetto. C. A. \& A. Lindgreen (2018)

The Emergence of Industrial Marketing Management as the Leading Academic Journal in Business-to-Business Marketing, Industrial Marketing Management, 69, pp. 5-12

Dorsch, M.J., S.R. Swanson \& S.W. Kelly (1998)

The role of relationship quality in the selection of vendors as perceived by customers, Journal of the Academy of Marketing Science, 26/2, pp. 128-142

Dowling, M.J., W.D. Roering, B.A. Carlin \& J. Wisnieski (1996)

Multifacted Relationships Under Coopetition, Journal of Management Inquiry, 5/2, pp. $155-167$

Dwyer, F.R., P.H. Schurr \& S. Oh (1987)

Developing buyer-seller relationships, Journal of Marketing, 51, pp. 11-27 
Ford, D., L.-E. Gadde, H. Håkansson \& I. Snehota (2011)

Managing business Relationships ( $3^{\text {rd }}$ ed.), John Wiley \& Sons.

Gadde, L.-E., L. Huemer \& H. Håkansson (2003)

Strategizing in industrial networks, Industrial Marketing Management, 32/5, pp. 357364.

Håkansson, H. \& J. Johanson (1993)

Industrial functions of business relationships, In: Sharma, D.D. (ed.), Industrial

Networks, Advances in International Marketing, 5, pp. 13-29

Järvensivu, T. and K. Möller (2009)

Metatheory of network management: A contingency perspective, Industrial Marketing Management, 38/6, pp. 654-661

Kozinets, R.V. (2002)

The Field Behind the Screen: Using Netnography for Marketing Research in Online Communities. Journal of Marketing Research, 39/1, pp. 61-72.

Lee, L.W.Y., Y. Tang, L.S.C. Yip \& P. Sharma (2018)

Managing customer relationships in the emerging markets - Guanxi as a driver of Chinese customer loyalty, Journal of Business Research, 86, pp. 356-365.

Leek, S., P. Naudé \& P.W. Turnbull (2003)

Interactions, relationships and networks in a changing world, Introduction to Special Issue Industrial Marketing Management, 32/3, pp. 87-90

Le Roy, F., G. Dagnino \& W. Czakon (2016)

Guest Editors' Introduction to the Special Issue on Coopetition and Innovation. International Studies of Management \& Organization, 46(1/2), pp. 130-135.

Leung, T., R.Y. Chan, K. Lai \& E.W. Ngai (2011)

An examination of the influence of Guanxi and xinyong (utilization of personal trust) on negotiation outcome in China: An old friend approach, Industrial Marketing Management, 40/7, pp. 1193-1205.

Mingers, J. (2008)

Exploring the dynamics of Journal citations: Modelling with s-curves, Journal of the Operational Research Society, 59, pp. 1013-1025

Möller, K. \& A. Halinen (2018)

IMP thinking and IMM: Co-creating value for business marketing, Industrial Marketing Management, 69, pp. 18-31

Möller, K. \& A. Halinen (2017)

Managing business and innovation networks - From strategic nets to business fields and ecosystems, Industrial Marketing Management, 67, pp. 5-22.

Möller, K. \& A. Halinen (1999) 
Business Relationships and Networks: Managerial Challenge of Network Era, Industrial Marketing Management, 28, pp. 413-427.

Möller, K. \& S. Svahn (2003)

Managing Strategic Nets: A capability perspective, Marketing Theory, 3, pp. 209-234.

Nalebuff, B.J., \& A.M. Brandenburger (1997)

Co-opetition: Competitive and Cooperative Business Strategies for the Digital Economy, Strategy \& Leadership 25/6, pp. 28-33.

Naudé, P. \& F. Buttle (2000)

Assessing relationship quality, Industrial Marketing Management, 29/4, pp. 351-361

Pagani, M. (2018)

"Chance favours the connected mind": Tribute to a world class editor, Industrial Marketing Management, 69, pp. 131-132

Patvardhan, S. (2013)

Prospection: Review and reflections on forward-looking behaviour of firms, Academy of Management Proceedings, 1, https://doi.org/10.5465/ambpp.2013.145

Payne, A. \& P. Frow (2005)

A Strategic Framework for Customer Relationship Management, Journal of Marketing, 69, pp. 167-176

Pattinson, S., J. Nicholson \& A. Lindgreen (2018)

Emergent coopetition from a sensemaking perspective: A multi-level analysis Industrial Marketing Management, 68, pp. 25-35

Ritter, T., I.F. Wilkinson \& W. J. Johnston (2004)

Managing in complex business networks, Industrial Marketing Management, 33, pp. 175-183

Walter, A., T. A. Müller, G. Helfert \& T. Ritter (2003)

Functions of industrial supplier relationships and their impact on relationship quality, Industrial Marketing Management, 32, pp. 159-169

Wang, C.L. (2007)

Guanxi vs. relationship marketing: Exploring underlying differences, Industrial Marketing Management 36, pp. 81-86.

Warren, D. E., Dunfee, T. W. and Li, N. (2004) Social Exchange in China: The DoubleEdged Sword of Guanxi, Journal of Business Ethics, 55/4, pp. 355-372

Zablah, A. R., D. N. Bellinger \& W. J. Johnston (2004)

An evaluation of divergent perspectives on customer relationship management: Towards a common understanding of an emerging phenomenon, Industrial Marketing Management, 33, pp. 475-489 